\title{
О ВОЗМОЖНОСТИ МОДИФИКАЦИИ РЕЦЕПТУРЫ ХЛЕБА «ФИТНЕС» ГРЕЧНЕВЫЙ ПУТЕМ ПРИМЕНЕНИЯ МУКИ ИЗ ОРЕХА ГРЕЦКОГО
}

\author{
Н.Л. Наумова, доктор технических наук, профессор \\ К.С. Каменева, студент \\ К.В. Щевьева, студент \\ Южно-Уральский государственный университет (НИУ) \\ E-mail:_n.naumova@inbox.ru
}

Ключевые слова: мука пшеничная, мука из ореха грецкого, смесь хлебопекарная, хлеб «Фитнес».

Реферат. Мука из грецкого ореха рассматривается специалистами пищевых технологий как источник полноченного белка, липидов, углеводов, минеральных веществ, витаминов и др. Цель исследований - изучение возможности применения муки из ореха греикого в технологии хлеба "Фитнес» гречневый с целью расширения ассортимента и повышения пищевой плотности хлебобулочных изделий. Объектами исследований явились: мука пшеничная хлебопекарная первого сорта; мука из ореха греикого; смесь хлебопекарная «Фитнес микс» гречневая; контрольные образиы хлеба "Фитнес» гречневый; опыт № 1 - с заменой $15 \%$ пшеничной муки на идентичное количество муки из ореха грецкого; опыт № 2 - с заменой $15 \%$ пшеничной муки на муку из ореха греикого и замещением $2 \%$ смеси хлебопекарной на аналогичное количество пшеничного глютена; опыт № 3 - с заменой $15 \%$ пшеничной муки на муку из ореха грецкого и замещением 4\% смеси хлебопекарной на пшеничный глютен; опыт № 4 - с заменой $15 \%$ пшеничной муки на муку из ореха греиякого и замещением $6 \%$ смеси хлебопекарной на пшеничный глютен. Исследовано качество и химический состав муки пшеничной, муки из ореха грецкого и смеси хлебопекарной гречневой. Выявлено превосходство муки из ореха грецкого над пшеничным сырьем по количеству ряда нутриентов. Определена приоритетная роль пшеничной муки в образовании пористости и формировании удельного объема хлеба. Проведена модификация рецептуры хлеба «Фитнес» гречневый.

\section{ABOUT THE POSSIBILITY OF MODIFYING THE RECIPE OF BREAD «FITNESS» BUCKWHEAT BY USING WALNUT FLOUR}

\author{
N.L. Naumova, Doctor of Technical Sciences, Professor \\ K.S. Kameneva, Student \\ K.V. Shchev'eva, Student \\ South Ural State University (National Research University)
}

Key words: wheat flour, walnut flour, baking mix, "Fitness" bread.

Abstract. Walnut flour is considered by food technology specialists as a source of complete protein, lipids, carbohydrates, minerals, vitamins, etc. The purpose of the research is to study the possibility of using walnut flour in the "Fitness" buckwheat bread technology in order to expand the range and increase the nutritional density of bakery products. The objects of research were: baking wheat flour of the first grade; walnut flour; bakery mix "Fitness Mix" buckwheat; control samples of "Fitness" buckwheat bread; experiment No 1 - replacing $15 \%$ of wheat flour with an identical amount of walnut flour; experiment No 2 - with the replacement of $15 \%$ of wheat flour with walnut flour and the replacement of $2 \%$ of the bakery mixture with a similar amount of wheat gluten; experiment No 3 -with the replacement of $15 \%$ of wheat flour with walnut flour and replacement of $4 \%$ of the bakery mixture with wheat gluten; experiment No 4 - with the replacement of $15 \%$ of wheat flour with walnut flour and the replacement of $6 \%$ of the bakery mixture with wheat gluten. The quality and chemical composition of wheat flour, walnut flour and a mixture of bakery buckwheat were investigated. The superiority of walnut flour over wheat raw materials in terms 
of a number of nutrients was revealed. The priority role of wheat flour in the formation of porosity and the formation of the specific volume of bread is determined. Modification of the "Fitness" buckwheat bread recipe was carried out.

Мука из грецкого ореха рассматривается специалистами пищевых технологий как источник полноценного белка, липидов (моно-, ди-, триглицеридов, свободных жирных кислот, фосфатидов), углеводов (сахаров, крахмала, клетчатки), минеральных веществ, витаминов, антиоксидантов (аскорбиновой кислоты, токоферола, каротина), фенольных соединений (танинов, флавонолов, катехинов), органических кислот и др. [1-4]. В этой связи известны технологии применения муки из ореха грецкого в производстве ацидофильного кисломолочного продукта с улучшенными органолептическими и функциональными свойствами; опыт использования концентрата ядра грецкого ореха в начинках для вафель с повышенным содержанием незаменимых аминокислот, полисахаридов, полиненасыщенных жирных кислот; разработана рецептура затяжного печенья, содержащего муку из грецкого ореха, богатую белком, железом, магнием, калием, медью, фосфором [4-7]. Описаны технологии получения мучных кондитерских и хлебобулочных изделий (пшеничных, ржаных и ржано-пшеничных) с добавлением муки из грецкого ореха [8]. Продукты питания, содержащие в составе порошок из скорлупы грецкого ореха, имеют низкий гликемический индекс [9].

Цель настоящего исследования - изучение возможности применения муки из ореха грецкого в технологии хлеба «Фитнес» гречневый с целью расширения ассортимента и повышения пищевой плотности хлебобулочных изделий.

Объектами исследований явились пробы сырья и модельные образцы хлеба:

- мука пшеничная хлебопекарная первого сорта (ГОСТ 26574-2017) производства ИП А. А. Михайлюта (Россия, Омская область, Кормиловский район, с. Победитель);

- мука из ореха грецкого (СТО 33974444-011-2016) производства ООО «Специалист» (Россия, Алтайский край, г. Бийск);

- смесь хлебопекарная «Фитнес микс» гречневая (ТУ 9295-040-18256266-2014) производства ООО «ИРЕКС» (Россия, Московская область, г. Люберцы). Состав: мука гречневая, отруби пшеничные, декстроза, мука пшеничная хлебопекарная высшего сорта, мука пшеничная солодовая, экстракт ячменный солодовый, эмульгатор Е 472e, глютен пшеничный, мука пшеничная солодовая обжаренная, стабилизаторы Е 341iii, Е 170, регулятор кислотности Е 263 , антиокислитель аскорбиновая кислота, ферментные препараты микробного происхождения;

- контрольные образцы хлеба «Фитнес» гречневый (ТУ 9110-006-18256266-2005 с дополнениями от 16.04.2008), вырабатываемые по регламентированной рецептуре (табл. 1);

- опытные образцы № 1 с заменой $15 \%$ пшеничной хлебопекарной муки первого сорта на идентичное количество муки из ореха грецкого. Дозировка нетрадиционного сырья была установлена опытным путем в серии предварительных исследований;

- опытные образцы № 2 с заменой $15 \%$ пшеничной хлебопекарной муки первого сорта на муку из ореха грецкого и замещением $2 \%$ смеси хлебопекарной «Фитнес микс» гречневой на аналогичное количество пшеничного глютена;

- опытные образцы № 3 с заменой $15 \%$ пшеничной хлебопекарной муки первого сорта на муку из ореха грецкого и замещением $4 \%$ смеси хлебопекарной «Фитнес микс» гречневой на пшеничный глютен;

- опытные образцы № 4 с заменой $15 \%$ пшеничной хлебопекарной муки первого сорта на муку из ореха грецкого и замещением $6 \%$ смеси хлебопекарной «Фитнес микс» гречневой на пшеничный глютен.

Применяли ускоренный способ приготовления теста, изделия выпекали формовыми массой нетто 0,5 кг. 


\begin{tabular}{|l|c|}
\hline \hline \multicolumn{2}{|c|}{ Рецептура хлеба «Фитнес» гречневый } \\
\hline \multicolumn{1}{|c|}{ Сырьевой состав и технологические параметры } & Расход сырья и параметры приготовления теста, кг \\
\hline Мука пшеничная хлебопекарная первого сорта & 80,00 \\
\hline Смесь хлебопекарная «Фитнес микс» гречневая & 20,00 \\
\hline Дрожжи хлебопекарные прессованные & 3,00 \\
\hline Соль поваренная пищевая & 2,00 \\
\hline Вода питьевая & По расчету \\
\hline Продолжительность брожения теста, мин & $15-20$ \\
\hline Температура теста начальная, ${ }^{\circ} \mathrm{C}$ & $26-28$ \\
\hline
\end{tabular}

Органолептическую оценку сырья проводили по ГОСТ 27558-87, готовой продукции - по ГОСТ 5667-65. Количество и качество клейковины определяли по ГОСТ 27839-2013, массовые доли веществ: влаги - по ГОСТ 9404-88, белка - по ГОСТ 10846-81, жира и золы - по МУ 4237-86. Содержание пищевых волокон устанавливали классическим методом [10]; кальция и магния - по Р 4.1.1672-03; железа, меди, цинка - по ГОСТ 30178-96; фосфора - по ГОСТ 30615-99; селена - по М 04-33-2004. Микроструктуру исследовали на растровом электронном микроскопе [11]. Удельный объем хлеба определяли по ГОСТ 27669-88, кислотность - по ГОСТ 5670-96, пористость - по ГОСТ 5669-96, содержание тиамина - по ГОСТ 29138-91, рибофлавина - по ГОСТ 29139-91.

Изучение органолептических показателей и сочетаемости применяемого сырья позволит предупредить формирование нежелательных изменений потребительских свойств готового хлеба. Установлено, что пшеничная мука не имеет видимых отклонений в сенсорных показателях качества от норм, регламентированных требованиями ГОСТ 26574-2017.

Для остального сырья были определены специфические характеристики, обусловленные как ботаническими особенностями культуры, так и ингредиентным составом. Так, мука из ореха грецкого представляет собой однородный порошок тонкого помола, серого цвета с кремовым оттенком, свойственного запаха, характерного сладковатого вкуса с легким вяжущим привкусом. Смесь «Фитнес микс» гречневая - сыпучий порошок с включением мелких отрубянистых частиц, особенно ощутимых при разжевывании. Цвет - светло-коричневый с красноватым оттенком, равномерный по всей массе, запах - свойственный, без посторонних тонов, вкус - свойственный гречневой крупе, более сладкий, без посторонних привкусов. Выявлена приемлемая сенсорная сочетаемость изучаемого сырья, позволяющая использовать его в составе сложной пищевой системы.

Исследование физико-химических показателей и химического состава сырья способствует пониманию вопросов формирования структуры мякиша, подъема и пищевой ценности хлеба. Определено, что базовые физико-химические показатели качества исследуемых проб сырья свойственны количественным диапазонам каждого из них. Влажность хлебопекарной смеси несколько отличается от аналогичного показателя изучаемых образцов муки (табл. 2), что необходимо учитывать при расчете количества воды, необходимого для приготовления теста. Несмотря на содержание в составе грецкого ореха глютелина [8], а в составе хлебопекарной гречневой смеси - муки пшеничной хлебопекарной высшего сорта и глютена пшеничного, определить качество и количество клейковинных белков в этих пробах сырья традиционным методом не представлялось возможным. Таким образом, в данном случае только пшеничная мука объективно принимает участие в образовании пористости и удельного объема хлеба. Это предположение было также подтверждено при изучении микроструктуры сырья с помощью растровой электронной микроскопии, где клейковинные белки в большом количестве были обнаружены в пшеничной муке и в виде единичных включений - в гречневой смеси (рис. 1). 


\begin{tabular}{|c|c|c|c|}
\hline \multicolumn{4}{|c|}{ Физико-химические показатели и пищевая ценность сырья } \\
\hline Определяемый показатель & Мука пшеничная & $\begin{array}{c}\text { Мука из ореха грец- } \\
\text { кого }\end{array}$ & $\begin{array}{l}\text { Смесь хлебопе- } \\
\text { карная }\end{array}$ \\
\hline Массовая доля влаги,\% & $11,30 \pm 0,30$ & $10,70 \pm 0,30$ & $7,30 \pm 0,20$ \\
\hline Массовая доля белка, \% & $10,20 \pm 0,40$ & $14,70 \pm 0,50$ & $11,50 \pm 0,40$ \\
\hline Количество клейковины,\% & $32,30 \pm 0,90$ & \multirow{2}{*}{-} & \multirow{2}{*}{-} \\
\hline Качество клейковины, ед. ИДК & $68,00 \pm 1,10$ & & \\
\hline $\begin{array}{l}\text { Массовая доля жира в пересчете на сухое } \\
\text { вещество, } \%\end{array}$ & $1,10 \pm 0,02$ & $23,50 \pm 0,50$ & $3,03 \pm 0,03$ \\
\hline $\begin{array}{l}\text { Содержание пищевых волокон, г/100 г } \\
\text { В том числе }\end{array}$ & $3,71 \pm 0,03$ & $8,63 \pm 0,04$ & $4,92 \pm 0,03$ \\
\hline растворимых & $0,90 \pm 0,02$ & $2,81 \pm 0,03$ & $1,12 \pm 0,02$ \\
\hline нерастворимых & $2,81 \pm 0,03$ & $5,82 \pm 0,05$ & $3,80 \pm 0,05$ \\
\hline Зольность в пересчете на сухое вещество, \% & $0,57 \pm 0,02$ & $4,17 \pm 0,07$ & $2,62 \pm 0,06$ \\
\hline \multicolumn{4}{|l|}{ Минеральные элементы, мг/кг } \\
\hline $\mathrm{P}$ & $1040,20 \pm 53,40$ & $6110,40 \pm 79,60$ & $4210,30 \pm 49,20$ \\
\hline $\mathrm{Ca}$ & $237,10 \pm 19,20$ & $3007,20 \pm 64,70$ & $3100,00 \pm 55,20$ \\
\hline $\mathrm{Cu}$ & $2,00 \pm 0,30$ & $15,90 \pm 1,80$ & $4,50 \pm 0,70$ \\
\hline $\mathrm{Fe}$ & $53,10 \pm 4,20$ & $113,20 \pm 6,10$ & $46,40 \pm 2,40$ \\
\hline $\mathrm{Mg}$ & $300,10 \pm 21,70$ & $3328,30 \pm 58,90$ & $1887,30 \pm 33,10$ \\
\hline $\mathrm{Zn}$ & $19,80 \pm 2,20$ & $40,50 \pm 3,30$ & $24,90 \pm 2,30$ \\
\hline $\mathrm{Se}$ & $0,26 \pm 0,10$ & $1,60 \pm 0,60$ & $1,10 \pm 0,40$ \\
\hline
\end{tabular}

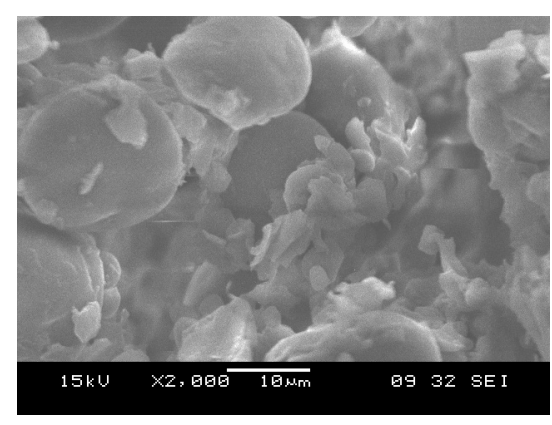

мука пшеничная

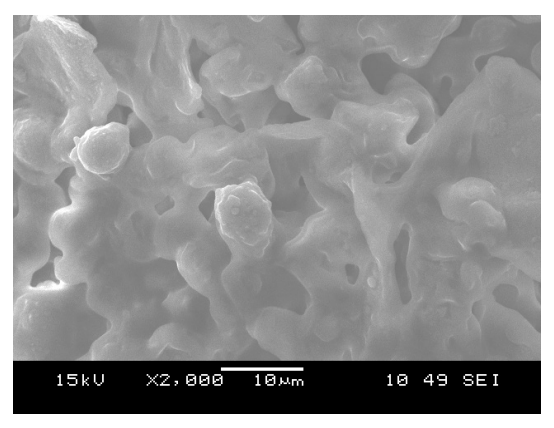

мука из ореха грецкого

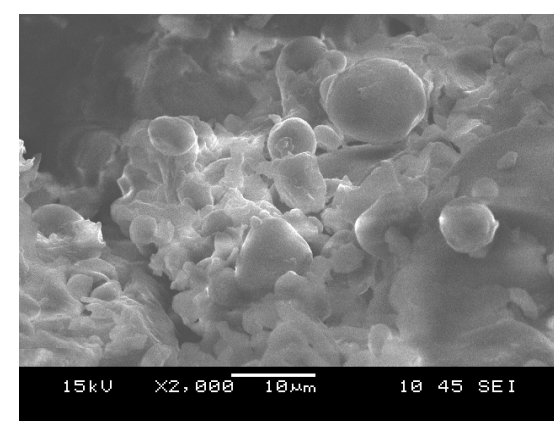

смесь хлебопекарная

Puc. 1. Микроструктура сырья (увеличение в 2000 раз)

Существенной разницы в количествах белковой фракции испытуемых образцов сырья, которая бы глобально могла снизить дефицит белка в новой модификации хлебобулочных изделий, не выявлено. Однако общеизвестно, что сбалансированность белка ореха грецкого по аминокислотному составу значительно превалирует над полноценностью белка пшеничного [4].

В дальнейших исследованиях акцент сделан на сравнительное оценке пищевой ценности пшеничной хлебопекарной муки первого сорта и муки из ореха грецкого с целью установления эффективности замены традиционного сырья на оригинальный растительный материал. Установлена относительно высокая масличность сырья из ореха грецкого. Так, содержание липидов в нетрадиционном материале превышает их содержание в пшеничной муке в 21 раз. Известно, что в масле ореха преобладают незаменимые полиненасыщенные жирные кислоты семейств $\omega-3, \omega-6, \omega-9$ [12]. Высокое содержание в масле $\delta$ - и $\gamma$-токоферолов (естественных антиоксидантов) предохраняет его липидный комплекс от окисления $[1,2]$. Нельзя не отметить превосходство муки из ореха как по общему содержание пищевых волокон, так и по количеству нерастворимой клетчатки. Повышение в хлебе содержания пищевых волокон за счет замещения сырья может изменить реологические свойства теста и готового продукта. 
Высокая зольность нетрадиционного сырья нашла свое отражение в его минеральном составе. Так, в муке из ореха грецкого по сравнению с пшеничным сырьем содержится больше следующих минеральных элементов: кальция - в 12,7 раза, магния - в 11,1, меди - в 7,9, селена - в 6,1, фосфора - в 5,8, железа и цинка - в 2 раза. Это обстоятельство позволит повысить пищевую плотность модифицированного хлеба и снизить дефицит отдельных минералов в пищевом рационе россиян. Очевидно также, что применение в рецептуре гречневой смеси комплекса пищевых добавок, а именно, ортофосфата, карбоната и ацетата кальция, суммарно к содержанию в гречневой муке фосфора и кальция, способствовало увеличению содержания в ней этих макроэлементов в 4 и 13,1 раза соответственно. Относительно высокий уровень содержания в хлебопекарной смеси селена, по-видимому, связан с включением в ее состав пшеничных отрубей, так как известно, что селена больше содержится именно в пшеничных отрубях, чем в зерне пшеницы, пшеничной или гречневой муке [13].

Следующим этапом стало испытание качества модельных образцов хлеба «Фитнес» гречневый, полученных из изучаемого сырья. Выявлено (рис. 2), что контрольные и опытные (опыт № 1 с заменой 15\% пшеничной муки на сырье из ореха грецкого) пробы имеют видимые невооруженным глазом различия только в цвете мякиша (в контроле - светло-коричневый, равномерный по всей массе, в опыте присутствует легкий темно-коричневый отте-

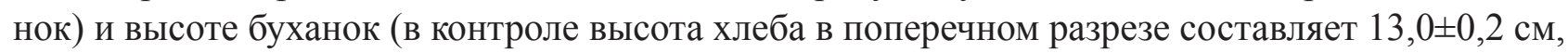
в опыте $-10,2 \pm 0,3$ см, что придает экспериментальным образцам некоторую приземистость). Во вкусе и запахе обеих проб хлеба присутствуют тона, свойственные гречневой культуре, без посторонних привкусов и запахов.

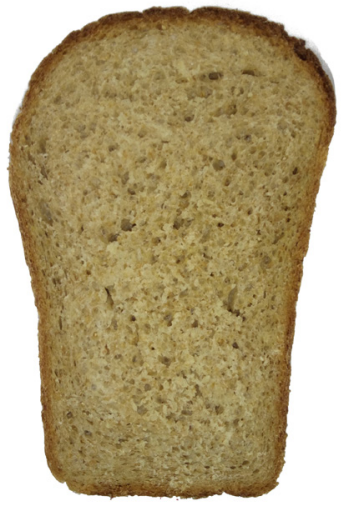

контроль

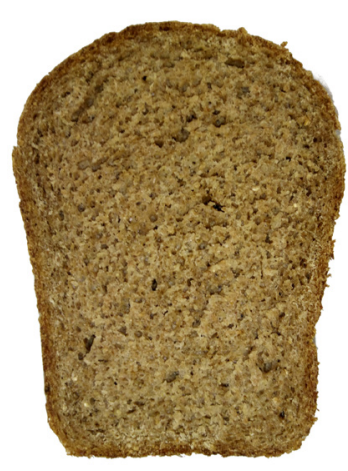

опыт № 1

Рис. 2. Внешний вид модельных образцов хлеба

Применение измерительных методов исследований позволило более детально изучить разницу в качестве испытуемых проб хлеба. Определено, что замещение пшеничной муки на сырье из ореха в рекомендуемой дозировке снизило удельный объем (на $11,1 \%$ ) и пористость (на 10,9\%) хлеба, но повысило кислотность (на 19,4\%) продукции сверх регламентированной нормы (табл. 3).

Таблица 3

Физико-химические показатели модельных образцов хлеба

\begin{tabular}{|l|c|c|c|}
\hline \multirow{2}{*}{ Определяемый показатель } & \multirow{2}{*}{ Норма по ТУ 9110-006-18256266-2005 } & \multicolumn{2}{|c|}{ Результаты испытаний } \\
\cline { 1 - 3 } & & контроль & опыт № 1 \\
\hline Удельный объем, см ${ }^{3 / \Gamma}$ & Не регламентируется & $3,79 \pm 0,03$ & $3,37 \pm 0,02$ \\
\hline Пористость,\% & & $73,50 \pm 0,90$ & $65,50 \pm 1,10$ \\
\hline Кислотность, град. & Не более 4,0 & $3,60 \pm 0,30$ & $4,30 \pm 0,20$ \\
\hline
\end{tabular}


К настоящему времени известен положительный опыт применения сухой пшеничной клейковины в составе хлебопекарной смеси при производстве хлеба из пшеничной муки первого сорта с дополнительным включением аглютенового сырья для увеличения пористости и удельного объема готовой продукции до стандартных уровней [14]. При производстве хлеба «Фитнес», согласно требованиям ТУ 9110-006-18256266-2005, возможна количественная вариация смеси гречневой в диапазоне до $20 \%$ без установления нижнего предела. Учитывая вышесказанное, нами было рассмотрено несколько вариантов модификации рецептуры опытных проб № 1 путем замены 2, 4 и 6\% смеси хлебопекарной «Фитнес микс» гречневой на пшеничный глютен (ГОСТ 31934-2012, марка «А», производитель ООО «Первый Диетический», Россия, г. Москва). Полученные результаты приведены в табл. 4.

Таблица 4

Физико-химические показатели модельных образцов хлеба после модификации

\begin{tabular}{|l|c|c|c|}
\hline \multicolumn{1}{|c|}{ Определяемый показатель } & Опыт № 2 & Опыт № 3 & Опыт № 4 \\
\hline Удельный объем, см ${ }^{3} / \Gamma$ & $3,53 \pm 0,02$ & $3,82 \pm 0,03$ & $3,71 \pm 0,02$ \\
\hline Пористость, \% & $69,20 \pm 0,80$ & $73,40 \pm 0,90$ & $72,20 \pm 0,70$ \\
\hline Кислотность, град. & $4,00 \pm 0,20$ & $3,70 \pm 0,30$ & $3,40 \pm 0,20$ \\
\hline
\end{tabular}

Установлено, что модифицированные образцы хлеба с замещением 4\% гречневой смеси на идентичное количество пшеничной клейковины по изучаемым показателям были максимально приближены к контрольной пробе на фоне формирования новой вкусовой особенности, а именно приятного орехового привкуса, и более светлого тона мякиша. В этой связи в дальнейших испытаниях использовали контроль и опыт № 3.

Определено, что влажность контрольных и модифицированных проб хлеба соответствует установленной норме - не более 46,0\% (табл. 5). Хлеб измененного рецептурного состава отличается повышенным содержанием растительного жира (в 3,9 раза), богатого полиненасыщенными жирными кислотами; белка (на 46,1\%); растворимого (на 47,5\%) и грубого (на 23,6\%) волокна, стимулирующего работу желудочно-кишечного тракта; минеральных элементов. В новой продукции отмечено относительно высокое содержание магния - в 2,1 раза, кальция - в 1,8, селена - в 1,7, фосфора - в 1,6, меди - в 1,4, железа - на 25,1\%, цинка - на $22,5 \%$.

Таблица 5

Физико-химические показатели и пищевая ценность хлеба

\begin{tabular}{|c|c|c|}
\hline Определяемый показатель & Контроль & Опыт № 3 \\
\hline 1 & 2 & 3 \\
\hline Массовая доля влаги,\% & $42,60 \pm 1,20$ & $44,30 \pm 1,30$ \\
\hline Массовая доля белка,\% & $6,50 \pm 0,40$ & $9,50 \pm 0,50$ \\
\hline Массовая доля жира в пересчете на сухое вещество,\% & $1,10 \pm 0,20$ & $4,30 \pm 0,40$ \\
\hline $\begin{array}{l}\text { Содержание пищевых волокон, г/100 г } \\
\text { В том числе } \\
\text { растворимых } \\
\text { нерастворимых }\end{array}$ & $\begin{array}{l}2,45 \pm 0,04 \\
0,59 \pm 0,02 \\
1,86 \pm 0,04\end{array}$ & $\begin{array}{l}3,17 \pm 0,05 \\
0,87 \pm 0,03 \\
2,30 \pm 0,05\end{array}$ \\
\hline Зольность в пересчете на сухое вещество, $\%$ & $0,62 \pm 0,05$ & $1,15 \pm 0,06$ \\
\hline \multicolumn{3}{|l|}{ Содержание минеральных элементов, мг/кг } \\
\hline $\mathrm{P}$ & $1110,10 \pm 44,70$ & $1825,80 \pm 51,30$ \\
\hline $\mathrm{Ca}$ & $502,20 \pm 15,30$ & $920,90 \pm 21,80$ \\
\hline $\mathrm{Cu}$ & $1,50 \pm 0,30$ & $2,10 \pm 0,50$ \\
\hline $\mathrm{Fe}$ & $32,30 \pm 2,40$ & $40,40 \pm 3,30$ \\
\hline $\mathrm{Mg}$ & $384,40 \pm 13,60$ & $825,80 \pm 19,80$ \\
\hline
\end{tabular}




\begin{tabular}{|c|c|c|}
\multicolumn{1}{|c|}{1} & 2 & Окончание табл. 5 \\
\hline $\mathrm{Zn}$ & $12,90 \pm 1,90$ & $15,80 \pm 1,70$ \\
\hline $\mathrm{Se}$ & $0,267 \pm 0,010$ & $0,465 \pm 0,025$ \\
\hline Содержание витаминов, мг/100 г & \\
\hline $\mathrm{B}_{1}$ (тиамин) & & $0,120 \pm 0,040$ \\
\hline $\mathrm{B}_{2}$ (рибофлавин) & $0,078 \pm 0,023$ & $0,23 \pm 0,06$ \\
\hline
\end{tabular}

Витаминная ценность экспериментальных проб хлеба «Фитнес» гречневый также возросла, в частности за счет повышения содержания тиамина и рибофлавина в 1,5-1,6 раза. Ликвидация витаминной и минеральной недостаточности рациона трудоспособного населения является важнейшим фактором поддержания его здоровья и работоспособности [15]. Неоспорима роль каждого из указанных микронутриентов в метаболизме организма человека.

Таким образом, доказана эффективность и установлена практическая возможность модификации рецептуры хлеба «Фитнес» гречневый путем замещения $15 \%$ пшеничной хлебопекарной муки первого сорта на муку из ореха грецкого и замены $4 \%$ смеси хлебопекарной «Фитнес микс» на аналогичное количество сухой пшеничной клейковины. Хлеб измененного рецептурного состава имеет хорошие потребительские свойства, отличается повышенным содержанием растительного жира, белка, пищевых волокон, богатым минеральным и витаминным составом.

\section{БИБЛИОГРАФИЧЕСКИЙ СПИСОК}

1. Камзолова О.И., Липская С.Л., Борисевич В.А. Химический состав ядра грецкого ореха в Беларуси // Садоводство и виноградарство. - 2006. - № 3. - С. 22.

2. Дмитриева А.Н., Макарова Н.В. Сравнительный анализ химического состава и антиоксидантных свойств орехоплодного сырья // Хранение и переработка сельхозсырья. - 2015. - № 12. - С. 40-43.

3. Макаренкова О.Г., Шевякова Л. В., Бессонова В.В. Природные микроэлементы орехов- неотъемлемая часть здорового питания // Вопросы питания. - 2016. - Т. 85, № S2. - С. 202.

4. Хуцишвили М.Г., Друкер О.В., Крючкова В.В. Мука грецкого ореха как растительный ингредиент в технологии обогащенного творожного продукта // Вестник Донского государственного аграрного университета. - 2017. - № 4-1 (26). - С. 127-133.

5. Мысаков Д. С. Исследование показателей качества мучного кондитерского изделия из смеси конопляной муки и муки из грецкого ореха // Исследования и разработки молодых ученых в решении актуальных проблем XXI века: сб. науч. ст. - Екатеринбург, 2017. - С. 77-83.

6. Шавыркина Н.А., Абрамова Ю.С. Изучение процесса сквашивания молока бактериями ацидофильной палочки (Lactobacillus acidophilus) при добавлении муки грецкого ореха // Технологии и оборудование химической, биотехнологической и пищевой промышленности: материалы VIII Всерос. науч. практ. конф. студентов, аспирантов и молодых ученых с междунар. участием / ФГБОУ ВПО Алт. гос. техн. ун-т им. И.И. Ползунова; Бийский технол. ин-т (филиал). - Барнаул, 2015. - С. 453-457.

7. Усовершенствование вафельных начинок с использованием концентрата ядра грецкого ореха / М. В. Обозная, Л. З. Шильман, Е. Ю. Кошель, Д. О. Бидюк, Ф. В. Перцевой // Аграрные конференции. - 2017. - № 1. - С. 11-12.

8. Васипов В. B., Вытовтов А. А. Обоснование использования муки из жмыха грецкого ореха в рецептуре мучных кондитерских и хлебобулочных изделий специализированного назначения // Пищевые инновации и биотехнологии: материалы IV Междунар. науч. конф. - 2016. C. $42-45$. 
9. Пономарева Е. И., Одинцова А.В. Оценка гликемического индекса флаксов для ахлоридного питания с различными обогатителями // Актуальные проблемы пищевой промышленности и общественного питания: материалы междунар. науч.-практ. конф. - 2017. - С. 225-228.

10. Руководство по методам анализа качества и безопасности пищевых продуктов / И. М. Скурихин, В. А. Тутельян. - М.: Брандес, Медицина, 1998. - 342 с.

11. Пашкеев И. Ю. Растровая электронная микроскопия и рентгеноспектральный микроанализ. - Челябинск, 2015. - 49 с.

12. Жирно-кислотный состав семян отборных форм ореха грецкого, индуцированного в Белгородской области / В.Н. Сорокопудов, А.А. Зинченко, Н.В. Назарова, Д.И. Писарев, Т. А. Резанова, Е. Г. Яковлева // Научные ведомости Белгородского государственного университета. Серия: Медицина и фармация. - 2011. - № 4-2 (99), т. 13. - С. 174-177.

13. Ковалевич 3.С., Головатый C.E. Накопление селена в зерне крупяных культур при использовании разных форм селеновых удобрений // Известия Национальной академии наук Беларуси. - 2010. - № 3. - С. 49-55.

14. Нестеренко И. К., Анисимова Л. В. Разработка мучной композитной смеси-концентрата на основе ячменной муки и пряностей // Ползуновский вестник. - 2015. - № 4-2. - С. 9-13.

15. Dasguta A., Klein K. Antioxidants in food, vitamins and supplements: prevention and treatment of disease. - Elsevier Inc., 2014. - 344 p.

\section{REFERENCES}

1. Kamzolova O. I., Lipskaya S. L., Borisevich V.A., Sadovodstvo $i$ vinogradarstvo, 2006, No. 3, pp. 22. (In Russ.)

2. Dmitrieva A.N., Makarova N.V., Hranenie i pe-rerabotka sel'hozsyr'ya, 2015, No. 12, pp. 40-43. (In Russ.)

3. Makarenkova O.G., Shevyakova L.V., Bessonova V.V., Voprosy pitaniya, 2016, vol. 85, No. S2, P. 202. (In Russ.)

4. Hucishvili M.G., Druker O.V., Kryuchkova V.V., Vestnik Donskogo gosudarstvennogo agrarnogo universiteta, 2017, No. 4-1 (26), pp. 127-133. (In Russ.)

5. Mysakov D.S., Issledovaniya i razrabotki molodyh uchenyh v reshenii aktual'nyh problem XXI veka (Research and development of young scientists in solving urgent problems of the XXI Century), Collection of Scientific Articles, Ekaterinburg, 2017, pp. 77-83. (In Russ.)

6. Shavyrkina N.A., Abramova Yu.S. Izuchenie processa skvashivaniya moloka bakteriyami acidofil'noj palochki (Lactobacillus acidophilus) pri dobavlenii muki greckogo orekha (Study of the process of fermentation of milk by bacteria of Acidophilus bacillus (Lactobacillus acidophilus) when adding walnut flour), Proceedings of the $8^{\text {th }}$ All-Russian Scientific and Practical, Barnaul, 2015, pp. 453-457. (In Russ.)

7. Oboznaya M.V., Shil'man L.Z., Koshel» E. Yu., Bidyuk D.O., Percevoj F.V., Agrarnye konferencii, 2017, No. 1, pp. 11-12. (In Russ.)

8. Vasipov V.V., Vytovtov A.A., Obosnovanie ispol'zovaniya muki iz zhmyha greckogo orekha $v$ recepture muchnyh konditerskih $i$ hlebobulochnyh izdelij specializirovannogo naznacheniya (Justification of the use of flour from walnut cake in the recipe of flour confectionery and bakery products for specialized purposes), Proceedings of the IV International Scientific Conference, 2016, pp. 42-45. (In Russ.)

9. Ponomareva E. I., Odincova A. V., Ocenka glikemicheskogo indeksa flaksov dlya ahloridnogo pitaniya s razlichnymi obogatitelyami (Evaluation of the glycemic index of flaxes for achloride nutrition with various fortifiers), Proceedings of the International Scientific and Practical Conference, 2017, pp. 225-228. (In Russ.) 
10. Skurihin I.M., Tutel'yan V.A., Rukovodstvo po metodam analiza kachestva i bezopasnosti pishchevyh produktov (Guidelines on methods for analyzing the quality and safety of food products), Moscow, Brandes, Medicina, 1998, 342 p.

11. Pashkeev I. Yu. Rastrovaya elektronnaya mikroskopiya i rentgenospek-tral'nyj mikroanaliz (Scanning electron microscopy and X-ray spectral microanalysis), Chelyabinsk, 2015, 49 p.

12. Sorokopudov V.N., Zinchenko A.A., Nazarova N.V., Pisarev D.I., Rezanova T.A., Yakovleva E. G., Nauchnye vedomosti Belgorodskogo gosudarstvennogo universiteta, 2011, No. 4-2 (99), vol. 13, pp. 174-177. (In Russ.)

13. Kovalevich Z. S., Golovatyj S. E., Izvestiya Nacional'noj akademii nauk Belarusi, 2010, No. 3, pp. 49-55. (In Russ.)

14. Nesterenko I. K., Anisimova L. V., Polzunovskij vestnik, 2015, No. 4-2, pp. 9-13. (In Russ.)

15. Dasguta A., Klein K. Antioxidants in food, vitamins and supplements: prevention and treatment of disease, Elsevier Inc., 2014, 344 p. 